no.

\title{
Marisa Mouton
}

\section{FIKSIONALITEIT IN DIE DRAMAWÊRELD1}

\begin{abstract}
The fictional drama world differs from the fictional world encountered in other literary genres, and the difference can be traced back to the link of the text with the performance.

A general, traditional view is that the fictional world of the dramatic text takes place in a fictional "here and now".

Elam has postulated a theory following a study of the fictional drama world. He uses a term from logical semantics, viz. the "theory of possible worlds" and adjusts this to enable him to speak of a dramatic possible world. Elam mentions three aspects which help towards the establishment of the fictional drama world, viz.

- the discovery of this world in medias res;

- the making specific of this world through the fictional characters; and

- the representation of this world in the performance.
\end{abstract}

1. Geldelike bystand van die Raad vir Geesteswetenskaplike Navorsing vir hierdie navorsing word hiermee erken. Menings in hierdie artikel uitgespreek of gevolgtrekkings waartoe geraak is, is dié van die outeur en moet nie beskou word as noodwendig dié van die Raad vir Geesteswetenskaplike Navorsing nie. 
Elam's exposition still does not indicate which aspects of the fictional drama world within the text coincide with or differ from those in the performance.

The fictionality of the drama world is linked to the aspect of the ostensible, and it is this link (implied in the text and edited in the performance) which characterizes the specific nature of the fictional in the drama genre and which distinguishes this genre from other literary genres.

\section{Inleiding}

Die dramateks word, soos die tekste in die ander literêre genres, as 'n fiksionele teks deur sy leser(s) beskou. Die leser se vertrekpunt is dat die aard van die gebeure en die status van die dramatis personae fiktief is. Binne die Westerse kultuur is die fiksionele aard van die dramateks dus 'n konvensie wat as sodanig deur die beoefenaars (skeppers en ontvangers) van hierdie kultuurverskynsel aanvaar word.

Die fiksionele dramawêreld verskil egter van die fiksionele wêrelde wat in die ander literêre genres gevind word - 'n verskil wat teruggevoer kan word na die teks se verbintenis met die opvoering. Aan hierdie aspek word nie net in die algemene literêre teorie min aandag gegee nie, maar ook binne die dramateorie vind die ondersoeker min verwysing daarna.

In tradisionele beskouings oor die fiksionele wêreld van die dramateks wys meeste teoretici daarop dat hierdie wêreld in 'n fiksionele 'hier en nou' afspeel. Hierdie opmerking is dikwels vir hulle 'n genoegsame omskrywing van die spesifieke aard van die dramawêreld en studies wat dié onderwerp verder voer is skaars. In der waarheid is dit ook so dat as mens net vassteek by 'n algemene omskrywing van die fiksionele wêreld en nie nagaan in watter mate die dramateks en die opvoering afsonderlik daardeur bepaal word nie, dit moeilik is om op so 'n aanmerking uit te brei.

Van die ouer teoretici het Nicoll (1962) wel die opvoering as uitgangspunt geneem en 'n paar interessante opmerkings oor fiksionaliteit gemaak.

Aangesien die teater die teenwoordigheid van beide die spelers en hulle toeskouers vereis, moet hierdie verhouding vervat word in 'n bespreking oor fiksionaliteit. Juis omdat die teater eintlik in twee ruimtes opgedeel kan word, naamlik die ruimte van die toeskouers (ouditorium) en die 
ruimte van die spelers (verhoog), kan 'n onderskeid tussen die fiksionele wêreld van die karakters en die werklikheid van die toeskouers gemaak word. Dit is die toeskouers se beskouing en belewing van die verhoogwêreld (m.a.w. dit is die direkte bemoeienis met 'n voorgestelde fiksionele wêreld) wat hierdie genre onderskei van die ander genres.

Soos baie ander teoretici verwerp Nicoll (1962:24) ook die veronderstelling dat daar ' $n$ absolute inlewing in hierdie fiksionele wêreld vanaf die kant van die toeskouers is: "the members of the audience enter into the world of illusion without completely leaving their own world of actuality". Die toeskouer bly op 'n sekere vlak deurgaans daarvan bewus dat dit wat hy sien en hoor net fiksioneel is en nie regtig gebeur nie. Hierdie besef voorkom egter nie dat hy hom nie kan inleef in die lotgevalle van die dramatis personae en selfs 'n katarsiservaring kan beleef nie.

By Nicoll en die ander ouer teoretici word min verdere bespreking van fiksionaliteit in die dramawêreld gevind en is dit eers met die werk van die drama- en teatersemiotici wat hierdie insigte en ander intensiewer bestudeer word.

\section{Die totstandkoming en die toeganklikheid van die fiksionele wêreld: Elam en die "possible world" - teorie}

Binne die drama- en teatersemiotiek is dit veral Elam wat die fiksionele dramawêreld bestudeer het. In sy boek (1980) wy hy 'n hele hoofstuk (Dramatic logic) aan hierdie aspek en gee nie alleenlik 'n besondere interessante uiteensetting van die fiksionele dramawêreld nie, maar toon ook terselfdertyd deur sy bespreking aan waarom ons die dramawêreld anders as byvoorbeeld die romanwêreld beleef.

In sy bespreking verduidelik Elam hoe die ontologiese status van die dramawêreld beskou kan word, hoe hierdie wêreld tot stand kom en hoe dié wêreld toeganklik (vir die leser/die toeskouer) is of gemaak word.

\subsection{Die ontologiese status van die fiksionele dramawêreld}

Om die ontologiese status van die dramawêreld te probeer bepaal het Elam hom gewend tot die logiese semantiek en die "theory of possible worlds" wat deur hulle ontwikkel is. Hierdie teorie is deur die logiese semantiek ontwikkel om die probleem van die referensiële status van 'n 
intensionele (konseptuele) objek (byvoorbeeld soos gevind in hipoteses, wense, ens) te omskryf. Binne hierdie teorie word die "moontlike wêreld" - die formele maaksel - omskryf deur sogenaamde "boeke" ("books"/"state descriptions") waarin dié wêreld se kenmerke vervat is. In teenstelling met die volledige 'boeke' wat oor die logiese semantiek se moontlike wêrelde opgestel kan word erken Elam dat daar nooit 'n volledige 'boek' oor die fiksionele dramawêreld opgestel kan word nie. Alle aspekte ten opsigte van 'n fiksionele wêreld sal nooit ten volle omskryf kan word nie.

Ten spyte van die verskille wat daar tussen bogenoemde voorbeelde uit die logiese semantiek en die dramawêreld bestaan, vind Elam hierdie term nogtans bruikbaar en wil hy dit so aanpas dat ons in plaas van 'n logiese moontlike wêreld sal praat van 'n dramatiese moontlike wêreld.

Hy noem kortliks die argumente wat die bestaan van so 'n konsep en die gebruik daarvan binne die dramagenre sou kon regverdig, naamlik:

(a) Die feit dat ons as lesers/toeskouers deurgaans vanuit 'n eie wêreld in staat is om die fiksionele wêreld (teks en opvoering) te beskou in terme van 'n 'ander' ("alternative context");

(b) Dat ons as lesers en toeskouers onder andere projeksies kan maak ten opsigte van gebeure, en dies meer binne hierdie 'ander' wêreld; die gapings ten opsigte van byvoorbeeld die voorgeskiedenis van die dramatis personae kan opvul, ensovoorts; en

(c) Dat die leser/toeskouer selfs twee of meer beskouings (subwêrelde) binne die 'ander' wêreld kan snap en daarmee kan omgaan soos in (b).

Die rede hoekom die leser/toeskouer wel so 'n onderskeid soos die fiksionele/"ander"/"moontlike" dramawêreld kan maak, is eenvoudig net te verklaar as iets wat hy as mens kan doen, met ander woorde as iets waartoe sy menslike brein instaat is.

Die betiteling van die fiksionele wêreld as 'n moontlike wêreld gee egter nog nie inligting oor hoe presies hierdie wêreld tot stand kom nie.

\subsection{Die totstandkoming van dle fiksionele dramawêreld}

Elam noem drie aspekte wat help met die totstandkoming van die fiksionele dramawêreld, naamlik: 
(a) Die ontdekking van hierdie wêreld in medias res;

(b) Die spesifisering van hierdie wêreld deur die fiksionele karakters;

(c) Die voorstelling van hierdie wêreld in die opvoering.

\subsubsection{Die ontdekking van hierdie wêreld in medias res}

Elam vestig ons aandag daarop dat die ontvanger van die fiksionele dramawêreld met ' $n$ wêreld kennis maak wat oënskynlik reeds bestaan en, individue ontmoet wat blykbaar 'n voorgeskiedenis besit (sulke inligting word meestal in die stuk gegee om die illusie van 'n bestaande wêreld te verstrek).

Hierdie tegniek wat die illusie skep dat 'n bestaande wêreld voorgestel word, help dus in 'n groot mate om hierdie wêreld vir die leser/ toeskouer tot stand te bring.

\subsubsection{Die spesifisering van hierdie wêreid deur die karakters}

Aangesien die drama anders as byvoorbeeld die roman baie minder gebruik maak van 'n verteller en die karakters dus meestal sonder bemiddeling aan die leser/toeskouers voorgestel word, is dit hierdie karakters self wat hulle wêreld met hulle woorde en handelinge skep. "Dramatic worlds ... are revealed through the persons, actions and statements which make them up, and not through external commentary." (Elam, 1980:112.) Hierdie beginsel formuleer Elam as die "reflexivity of the W" (W = dramawêreld - M.M.), met ander woorde die uitinge en die handelinge van die karakters weerkaats, in 'n sekere sin, terug na dieselfde karakters om sodoende hulle wêreld te skep.

\subsubsection{Die voorsteiiing van hierdie wêreid in die opvoering}

Behalwe dat die dramawêreld as 'n 'bestaande' wêreld ervaar word ('n gevolg van die gebruikmaking van die in medias res - tegniek) en hierdie wêreld ook deur die karakter self geskep word, is dit ook moontlik om hierdie wêreld fisies voor te stel. Anders as in narratiewe tekste (byvoorbeeld die roman) word die dramawêrelde aan die toeskouer getoon as "'hypothetically actual' constructs, since they are 'seen' in progress 'here and now' without narratorial mediation" (Elam, 1980: 111).

Ostensie wat die opvoering onderlê dra in 'n groot mate by daartoe dat 
die toeskouer die fiksionele wêreld as 'n wêreld wat hy herken en waarin hy hom kan inleef, ervaar. Hy sien en hoor naamlik persone en dinge wat, alhoewel hulle as fiksioneel gepresenteer word, nogtans fisiese gestaltegewing gekry het in die opvoering. Binne hierdie fiksionele wêreld wat sigbaar en hoorbaar is, word ook die dramatis personae gesien en gehoor, en versterk hulle onderlinge verwysings na hierdie wêreld en na mekaar (deur soms met gebare na mekaar te wys) die illusie van 'n bepaalde wêreld.

Om die fiksionele wêreld voor te stel moet fisiese persone, ruimtes, objekte, en dies meer egter vanuit die werklikheid gebruik word om hierdie fiksionele/"ander" wêreld te kan vertoon aan die toeskouers. Hierdie persone, ruimtes, objekte mak dus asof (die "make-believe" van die teater), hulle die fiksionele karakters, ruimtes, objekte is - 'n verskynsel wat mens met 'n formule $x$ staan vir $y$ kan opsom (akteur staan vir karakter $_{y}$, verhoog staan vir fiksionele ruimte $_{y}$, ens). Soos wat Elam aandui, kry ons in die werklike opvoering dat die akteurs in hulle omgang met hierdie wêreld voorgee asof hulle, hul ruimte en die objekte in daardie ruimte, die fiksionele referente self is. "The actor will indicate the stage, the set and his fellow actors as if they were the dramatic referents themselves, so as to strengthen the illusion of direct presentation of the constructed world" (1980:113).

\subsection{Die toeganklikheid van die fiksionele wêreld}

In sy bespreking oor die fiksionele dramawêreld se toeganklikheid lê Elam hom hoofsaaklik toe op 'n bespreking van die toeganklikheid daarvan vir die toeskouer in die opvoering en word die leser se toegang daartoe deur die dramateks nie bespreek nie. (Vir so 'n bespreking sien 1.2.)

Dit is seker so dat sowel die toeskouer as die leser se verbeelding toegang tot 'n fiksionele wêreld moontlik maak. Die 'glo' in 'n 'ander'/ moontlike wêreld is 'n verbeeldingsprong wat die leser/toeskouer (moet) maak. In die opvoering kan die voorstelling van die fiksionele wêreld so 'n sprong soms makliker maak, maar het dit ook tot gevolg dat die hele saak van die fiksionele in die teater komplekser word. In sy bespreking van toeganklikheid gebruik Elam weer beskouings uit die "possible world"-teorie om hierdie saak te verduidelik. Daarvolgens word toeganklikheid tussen die wêreld van die speler (wat hom bevind in 'n ruimte wat die fiksionele wêreld voorstel, naamlik die verhoog) en die wêreld van die toeskouer (wat hom bevind in die werklike ruimte 
van 'n ouditorium) gesien in terme van 'n verhoudingsopset tussen die twee. Die formule $\mathrm{W}_{1} \mathrm{RW}_{2}$ (waar $\mathrm{W}_{1}=$ een wêreld, $\mathrm{R}=$ relasie tussen, $\mathrm{W}_{2}=$ ander wêreld) word nou gebruik om die verhouding tussen die twee wêrelde wat deur die opvoering betrek word, te beskryf. Die formule $\mathrm{W}_{1} \mathrm{RW}_{2}$ hou in dat $\mathrm{W}_{2}$ toeganklik is vir $\mathrm{W}_{1}$, en as die omgekeerde ook moontlik is, naamlik $\mathrm{W}_{2} \mathrm{RW} \mathrm{W}_{1}\left(\mathrm{~W}_{1}\right.$ is toeganklik vir $\mathrm{W}_{2}$ ) word die verhouding tussen hierdie twee wêrelde as simmetries betitel. As slegs een van hierdie relasies moontlik is, byvoorbeeld slegs $W_{1} R W_{2}$ word die verhouding tussen hulle asimmetries genoem.

As teruggekeer word na die verhouding tussen die fiksionele dramawêreld van die verhoog en die werklike wêreld van die gehoor, dan is dit so dat die fiksionele wêreld wel toeganklik vir die toeskouer is, terwyl die karakters konvensioneel nie toegang tot die werklikheid het nie, met ander woorde die verhouding tussen hierdie twee wêrelde is asimmetries: $W_{w} R W_{f}\left(W_{w}=\right.$ werklike wêreld, $W_{f}=$ fiksionele wêreld $)$.

Die verklaring vir die toeganklikheid van die fiksionele wêreld voer Elam grootliks terug na die feit dat die dramawêreld altyd gebaseer is op die werklikheid. As dit nie die geval was nie, dan sou letterlik alles binne 'n dramateks/opvoering gespesifiseer moes word om dit vir ons (die ontvangers) verstaanbaar (en dus toeganklik) te maak. "No drama in history has undertaken to set up an alternative world in such an encyclopedic fashion. Instead, it is assumed that the semantic and cultural rules operative in $\mathrm{W}_{\mathrm{d}}$ (fiksionele dramawêreld - M.M.) will be those exercised in the spectator's social context." (1980:140.)

As die fiksionele wêreld geen ooreenstemming met die werklikheid getoon het nie, sou so 'n wêreld vir die toeskouers daarvan geheel en al ontoeganklik gewees het. Elam wys daarop dat selfs in stukke wat oënskynlik wegbreek van die werklikheid en blykbaar 'n wêreld skep wat heeltemal verskil van die gewone wêreld (byvoorbeeld die absurde teater, surrealistiese stukke, ens.) ons hierdie stukke juis beleef teen die agtergrond van die gewone en hulle daarvolgens tipeer as ongewoon. ${ }^{2}$

Aangesien Elam oortuig is daarvan dat die verhouding tussen die fiksionele wêreld van die verhoog en die werklikheid van die gehoor een

2. In 'n artikel van O.O. Revzina en I.I. Revzin (1975) oor Ionesco se absurde stukke toon hulle in detail aan hoe die ongewone taalgebruik in hierdie werke afwykings is van die normale taalwetmatighede met ander woorde ook die oënskynlik heeltemal absurde staan in 'n spesifieke verhouding tot die normale. 
is wat asimmetries is, verklaar hy ook 'deurbrekings' vanaf die kant van die fiksionele ruimte na die gehoor toe as 'n illusie; as 'n truuk wat op die gehoor gespeel word.

\section{Fiksionaliteit: die dramateks en die opvoering}

Alhoewel Elam 'n goeie uiteensetting gee van die fiksionele dramawêreld se aard, totstandkoming en toeganklikheid, is dit nie altyd uit sy bespreking duidelik of bogenoemde beskouings oor die fiksionele dramawêreld op sowel die opvoering as op die dramateks van toepassing is nie. As ons aanneem dat die term fiksionele dramawêreld wel so oorkoepelend gesien moet word, is dit nog steeds nie duidelik watter aspekte van die fiksionele dramawêreld binne die dramateks ooreenkom of verskil van dié in die opvoering nie.

Vervolgens word 'n hipotese voorgelê wat die aspek van fiksionaliteit binne die dramateks en die opvoering op 'n vergelykende manier beskou. Erkenning word gegee aan die insigte wat hieroor uit die drama- en teatersemiotiek (veral Alter, Elam en Kowzan) verkry is, alhoewel onmiddellik gestel moet word dat die uitwerk van die onderstaande model 'n eie poging is.

As uitgangspunt word beweer dat die verbintenis wat daar tussen die dramateks en die opvoering bestaan, terug te herlei is na ' $n$ enkele belangrike aspek, naamlik ostensie. Terwyl ostensie makliker aanvaar kan word as dié kenmerk van die opvoering (m.a.w. die feit dat die fiksionele wêreld op die verhoog fisies uitgebeeld word), is dit dalk moeiliker om terselfdertyd te aanvaar dat ostensie amper net so 'n belangrike rol in die dramateks as in die opvoering speel. Voorstelling van die fiksionele hou dus in dat daar twee vlakke binne sowel die opvoering as die dramateks onderskei gaan word, naamlik (A). Die fiksionele vlak, en (B). Die voorstellingsvlak.

Eerstens word die dramateks ten opsigte van hierdie twee vlakke bespreek.

\section{1 (A) Die fiksionele vlak in die dramateks}

Die ontvanger van die dramateks - die leser - kry sy inligting oor hierdie fiksionele dramawêreld vanuit die dialoog (taal) en die didaskalia waaruit die teks saamgestel is. Hierdie inligting kan ook onder meer 
informasie verskaf wat 'n visuele en 'n ouditiewe aard is (byvoorbeeld hoe die karakter(s) lyk/klink/beweeg/gebare maak, ens., hoe die ruimte lyk en klink, ens.). Hierdie tipe inligting help die leser in 'n groot mate dus om die fiksionele dramawêreld in sy verbeelding te kan visualiseer, met ander woorde die leser word gehelp om 'n verbeelde voorstelling van die fiksionele wêreld in sy gedagtes te vorm. (Dit gaan hier nie oor die feit of hierdie verbeelde voorstelling enigsins ooreenkom met 'n werklike voorstelling al dan nie, maar wil bloot uitwys dat ook die leser van die dramateks voorstelling gebruik om hierdie fiksionele wêreld vir homself te skep en toeganklik te maak.)

\section{2 (B) Die voorstellingsvlak in die dramateks}

Die dramateks kan egter ook op 'n tweede manier gelees word. 'n Leser kan dit naamlik lees om nie die fiksionele dramawêreld te leer ken nie, maar om eerder inligting te verkry ten opsigte van hoe hierdie wêreld en sy inwoners op 'n verhoog en deur middel van akteurs voorgestel kan word. Nou lees die leser (dikwels 'n regisseur/akteur, e.a.) die dialoog en die didaskalia op so 'n wyse dat moontlike inligting oor hoe hierdie fiksionele wêreld voorgestel kan word, versamel word. Hierdie lees is dus 'n verbeelde voorstelling van die/'n moontlike opvoering.

Vervolgens word na die opvoering ten opsigte van hierdie twee vlakke gekyk om te bepaal hoe dit van die dramateks verskil.

\section{3 $\left(A_{1}\right)$ Die fiksionele vlak in die opvoering}

Terwyl die leser van die dramateks sy inligting oor die fiksionele wêreld kry deur die taaltekens te lees, word die fiksionele wêreld in die opvoering vir die toeskouer voorgestel - hy kan hierdie wêreld dus sien en hoor. Die verbale tekens van die teks word in die opvoering omgesit in (hoofsaaklik) visuele en ouditiewe tekens. Waar die leser 'n verbeelde voorstelling van die fiksionele wêreld maak, kry die toeskouer 'n werklikelaktuele voorstelling van die fiksionele wêreld.

In die opvoering is hierdie vlak 'n komplekser een as in die dramateks. Aangesien die fiksionele wêreld nie self te voorskyn kan kom vir die toeskouer nie, maar van werklike/fisiese persone en objekte moet gebruik maak om hulle te verteenwoordig (m.a.w. die $\mathrm{x}$ staan vir y-beginsel), kan ons sê dat die fiksionele en die ostensiewe hier hand aan hand gaan. Dit is seker ook as gevolg van hierdie noue verwantskap tussen die fiksionele element aan die een kant en die fisiese verteen- 
woordiger aan die anderkant dat juis op hierdie vlak die toeskouer soms die twee kan verwar. ${ }^{3}$

'n Bespreking van die fiksionele wêreld in die opvoering kan dus nie nalaat om die voorstellingsvlak te betrek nie, omdat hierdie fiksionele wêreld tog nie bestaan vir die toeskouer as dit nie voorgestel word nie.

\section{4 $\left(B_{2}\right)$ Die voorstellingsvlak in die opvoering}

Net soos wat 'n leser die dramateks op 'n ander wyse kan lees as bloot om vertroud te raak met die fiskionele wêreld, kan ook die toeskouer die opvoering soms as opvoering ervaar, met ander woorde hy sal dan die akteur nie sien in sy rol as voorgestelde karakter nie, maar wel as die akteur self, die verhoog nie as 'n voorgestelde fiksionele ruimte nie, maar as die verhoog self, en dies meer.

Teenoor die leser wat op die vlak van voorstelling die dramateks lees as 'n verbeelde voorstelling van 'n moontlike opvoering, ervaar die toeskouer dus 'n werklike voorstelling van 'n spesifieke opvoering as opvoering.

\section{5 'n Aantal opmerkings oor hierdie model}

1. Die tweede wyse waarop die leser die dramateks kan lees (1.3.2), naamlik as inligting ten opsigte van 'n potensiële opvoering daarvan, word moontlik gemaak omdat, nie net die didaskalia so 'n lees impliseer nie, maar ook omdat die taal self deur die gebruik van deiktiese uitdrukkings ${ }^{4}$ dit aandui (byvoorbeeld deur persoonlike voornaamwoorde soos ek en jy, en tydruimtelike verwysings soos hier en nou, wat 'n direkte gespreksituasie kenmerk, te gebruik). Met ander woorde die besondere taalgebruik van die teks suggereer reeds die moontlikheid van voorstelling.

2. Uit bogenoemde is dus afgelei dat ostensie verskuild is in die teks. In die omskrywing van die band tussen die teks en die opvoering moet dit

3. Daarom kry ons dikwels dat die akteur heldeverering ontvang, terwyl dit in der waarheid die karakter is wat hy vertolk wat sulke bewondering eintlik moet kry, en omgekeerd, word die toeskouer soms geïrriteer deur 'n karakter, terwyl dit eintlik die akteur is wat sy rol swak vertolk wat hierdie reaksie uitlok.

4. A. Serpieri e.a. se artikel (1981) gee 'n uiteensetting van hoe belangrik deiksis vir die dramateks is, en dui aan hoe die taal van die dramateks reeds sy verbintenis met die opvoering toon. 
as die primêre gegewe aangetoon word, aangesien die potensialiteit tot ostensie wat in die dramateks skuil, wel in die opvoering gerealiseer word.

3. 'n Aspek wat dikwels as kritiek ingebring word teen 'n studie wat die teks en die opvoering wil saamvoeg, is die verskynsel dat daar talle opvoerings van een teks moontlik is en dat opvoering(s) van die teks nie alleenlik van mekaar kan verskil nie, maar soms heeltemal uiteenlopende voorstellings is. Om na alle moontlike opvoerings van 'n teks te verwys is uiteraard onmoontlik - nie net sal geen ondersoeker van almal bewus kan wees nie (en gevolglik nooit almal kon bygewoon het nie) maar selfs as hy 'n paar verskillende opvoerings van dieselfde teks gesien het, sal hy moeilik 'n spesifieke keuse uit daardie kan maak om te sê dit is die opvoering van die teks. Die uitgangspunt wat hier ingeneem word, is dat die teks wel uitwys na ' $n$ moontlike opvoering en dat hierdie moontlikheid nie alleenlik verskeie opvoerings van hierdie teks nie uitsluit nie, maar dat dit selfs waarskynlik is dat daar vele opvoerings van dieselfde teks gemaak kan word. Die rol wat aan die geimpliseerde ostensiewe aard van die teks toegeken is, maak voorsiening daarvoor dat die verwerkliking/verwesenliking van hierdie potensiaal (wat van hoofsaaklik visuele en ouditiewe wyses van verwesenlikings sal gebruik maak) vele vorme kan aanneem.

Die 'neutrale' wyse waarop sommige inligting van visuele/ouditiewe aard in die teks gegee word, behoort ons alreeds daarop bedag te maak dat ' $n$ voorstelling van sulke inligting op 'n verskeidenheid van maniere kan geskied.

Om hierdie punt mee af te sluit kan ook genoem word dat selfs die verbeelde voorstelling van die fiksionele wêreld deur een leser sal verskil wat dié van ('n) ander leser(s) daarvan sal/kan maak. Die potensiaal tot verskeidenheid moet eenvoudig net erken en aanvaar word as deel van die unieke aard van die dramagenre en moet nie as 'n struikelblok gesien word as daar na die verhouding tussen die teks en die opvoering gekyk word nie.

4. As 'n verdere uitvloeisel van (3) kan ons beweer dat die opvoering wel 'n meer komplekse karakter as die dramateks ten opsigte van die verhouding tussen die twee vlakke (fiksionele en voorstelling) vertoon; want die regisseur is naas ontvanger ook sender. Opsommend kan die verhouding tussen die twee vlakke binne die dramateks en die opvoering soos volg diagrammaties getoon word: 


\begin{tabular}{|l|ll|}
\hline \multicolumn{1}{|c|}{ Dramateks } & \multicolumn{1}{c|}{ Opvoering } \\
\hline A. & $\begin{array}{l}\text { Fiksionele vlak } \\
\text { Verbeelde voorstelling van die } \\
\text { fiksionele wêreld }\end{array}$ & A. $\begin{array}{l}\text { Fiksionele vlak } \\
\text { Werklike voorstelling van die } \\
\text { fiksionele wêreld met ander } \\
\text { woorde betrek ook ostensie }\end{array}$ \\
B. Voorstellingsvlak & $\begin{array}{l}\text { Voorstellingsvlak } \\
\text { Verbeelde voorstelling van die } \\
\text { of 'n moontlike opvoering daar- } \\
\text { van }\end{array}$ & $\begin{array}{l}\text { Werklike voorstelling van 'n } \\
\text { spesifieke opvoering, met } \\
\text { ander woorde die opvoering as } \\
\text { opvoering }\end{array}$ \\
\hline
\end{tabular}

\section{Ten slotte}

Bogenoemde model is 'n vereenvoudigde uiteensetting van die twee vlakke (fiksionele en voorstelling) wat binne die dramateks en die opvoering onderskei kan word. In die praktyk neem hierdie twee vlakke (en veral as hulle in 'n wisselwerking mekaar beïnvloed) vele vorme in spesifieke dramatekse en opvoerings aan.

Die fiksionaliteit in die dramawêreld is gekoppel aan die aspek van ostensie, en dit is hierdie verbintenis (geimpliseerd in die teks en gerealiseer in die opvoering) wat die spesifieke aard van die fiksionele in die dramagenre kenmerk en dié genre onderskei van die ander literêre genres. Die fiksionele is uiteraard die een aspek wat alle ander elemente binne die dramateks en die opvoering onderlê. Enige bespreking van die spesifieke elemente in die teks en die opvoering, soos die dramatis personae, die tydruimte, en dies meer, sal deurgaans gedoen moet word teen die agtergrond van die fiksionele raam wat daarom geplaas word.

\section{BIBLIOGRAFIE}

ALTER, J. 1981. From text to performance. Poetics Today 2(3):133-139.

ELAM, K. 1980. The semiotics of theatre and drama. New York: Crown Publishers, Inc.

KOWZAN, T. 1968. The sign in the theatre. An introduction to the semiology of the art of the spectacle. Diogenes 61:52-80.

NICOLL, A. 1962. The theatre and dramatic theory. London: George G. Harrap \& Co. Ltd.

REVZINA, O.O. \& REVZIN, I.I. 1975. A semiotic experiment on stage: the violation of the postulate of normal communication as a dramatic device. Semiotica XIV 3(14): $245-268$. 
SERPIERI, A. e.a. 1981. Toward a segmentation of the dramatic text. Poetics Today 2(3): $163-200$. 